appointing, the authors have done much better. The two related articles by Rudolph and Wilhelmi, and by Dianov et al., present a splendid account of ultrashort pulse compression and optical solitons. On balance, this looks like a good series which will certainly be used as a source of reference material once the production difficulties are overcome.

Peter Knight is in the Blackett Laboratory, Imperial College, London SW7 2BZ, UK.

\section{Into the shadows}

\author{
Robert N. Proctor
}

\begin{abstract}
Health, Race and German Politics between National Uniflcation and Nazism 1870-1945. By Paul Weindling. Cambridge University Press: 1989. Pp. 641. £55, \$69.50.
\end{abstract}

IN recent years there has been an explosion of historical writing on science and medical policy under the Nazis. Paul Weindling's new book adds substantially to this literature, tracing the growth of German eugenics from the utopian social darwinism of the $1890 \mathrm{~s}$ to the criminal medicine of the Nazis. Based on extensive research in East and West German archives, Weindling shows that the rise of German eugenics must be understood in the context of public-health and welfare institutions, and not simply as an offshoot of Aryan supremacist ideology.

Many of these themes are familiar, but much new detail is added: on Ploetz's private antisemitism, on publisher J. F. Lehmann's Freikorps activity, and on the fears of venereal disease that generated Ibsen's Ghosts. Weindling describes Haeckel's hierarchical organicism, Forel's early experiments with castration, Voronoff's experiments transplanting monkey testicles (into humans for the purposes of rejuvenation), and the early anti-alcohol movement. His account mixes the ominous and the downright silly, as we hear not only about early plans for euthanasia, but also about the convictions within Ploetz's circle that, as humans are mammals, they should dress in clothing made from mammalian fibres.

Weindling does an interesting job tracing the appeal to biological metaphors in political life - metaphors of the cellstate and the cell-army, comparisons of plasma to soldiers and of the genome to the general staff. Carl Correns compared hereditary units to machine-gun bullets; others complained about the rising "monopoly of the nucleus" (Kernmono$p o l)$ in concepts of cellular function. Weindling is sensitive to the changing political fortunes of scientific theories, from the ban in 1879 on evolution in Prus- sian schools (when biology became "a casualty of the anti-socialist laws") to the Nazi endorsement of Weismann's principle of the immutability of the germ plasm. Biologically based politics are described as a strategy for German national unification, one whose political character changed with the changing political fortunes of nationalism.

The strength of the work is its voluminous detail - Weindling has examined an extraordinary range of sources. This strength is related to the book's primary weakness, insofar as the steady stream of details sometimes seems haphazardly organized, with insufficient attention to matters of style. We hear about publichealth reformers developing "an institutional infrastructure in associations and the state for the provision of welfare", and similar convolutions. The text is further dulled by excessive use of the passive voice ("a surge in population growth meant that a range of political structures and values were resented as restrictive") and occasional repetitions.

If there is an overarching theme to the work, it is that an "ideology of professional expertise" helped to bring about the authoritarian medicine we associate with the Nazi era. Science and medicine "served to define the social status of intellectual elites", as eugenics ideals merged with the goals of the nascent welfare state. The Weimar republic was unstable because technocratic professionals erected antidemocratic and coercive social structures.

At times, I found myself uneasy with the repeated allusions to the "rule of professional elites". (After all, there have been other states with equally strong professional elites, where fascism was not the consequence.) Weindling suggests that eugenics was a barrier to democratization because "its scientific claims required professional expertise". On such criteria most medicine - and probably most science must be judged antidemocratic. Eugenics was generally hostile to democracy, not because it was promoted by professionals, but rather because it posited a hierarchy of races and/or lives judged worthy or unworthy of living. The fact that eugenicists were professionals (most were physicians) aided them in achieving their goals, but it did not exhaustively define their politics. Professionals, after all, were also involved in resistance to eugenics and to fascism - as Weindling takes pains to illustrate. Professionalism and democracy (or science and democracy) are not inherent opposites.

Weindling distinguishes between technocrats and ideologues in the racial hygiene movement. Ideologues championed racial purity and a romantic return to the past; technocrats championed professional power and "value-neutral" science. If there is a salient feature of Nazi racial hygiene, however, it is that the boundary between technocrats and ideologues was not a fast one. Was Otmar von Verschuer an ideologue or a technocrat? The racialist rhetoric of Lenz or Fischer or Verschuer was certainly as odious as that of Streicher or Wagner; the fact that it was clothed in science did not make it any less ideological. Postwar denazification officials pondered whether men such as Verschuer should be considered "racial fanatics" or "dedicated scientists"; few recognized that it was possible to have been both. The American mentioned by Nachtsheim (and cited by Weindling) who stated that anthropologists were " 1,000 times more guilty than the average idiotic SS man" was probably not far from the truth.

In a volume of such a scope there are bound to be a few errors: J. F. Lehmann, the notorious publisher of racial hygiene (whose name now adorns every bookstore of the West German Medical Association), joined the Nazi party in 1920 , not in 1932 as Weindling states. This qualified Lehmann to receive the very first Goldene Ehrenzeichen, an honour bestowed only upon the first 100,000 members of the party. Weindling elsewhere states that most racial hygienists remained "aloof" from the Nazi party, supporting this with statistics to the effect that only one in four members of the Munich Society for Racial Hygiene had joined the party by January 1933 , before Hitler's rise to power. This is hardly evidence of apathy. In attempting to rectify the traditional assumption linking eugenics exclusively with the political right, Weindling goes a bit too far in the opposite direction, characterizing eugenics as a "central focus" of the Socialist Doctors Association. A few socialists supported eugenics, but not to the extent that parties of the right did (with the notable exception of Catholics).

Weindling's is not likely to be a popular book; it is not designed to be. But he has clearly helped to illuminate the shadows that historians of medicine have tended to avoid in their focus on the brighter side of their subject.

Robert N. Proctor is at the New School for Social Research, New York, New York 10011, USA.

- R. N. Proctor's book Racial Hygiene: Medicine under the Nazis has just appeared in paperback. Publisher is Harvard University Press, price $£ 11.95, \$ 14.95$. For review see Nature 334, 573 (1988).

- To be published next week by Basic Books is The Genocidal Mentality: Nazi Holocaust and Nuclear Threat, by psychiatrist R. J. Lifton and sociologist E. Markusen. The authors attempt to show how the demands of professionalism, the pressures of bureaucracy and dissociative processes such as "psychic numbing" enable scientists and strategists to "remain sane in the service of social madness". Price is $\$ 22.95$. 